\title{
TREND IN TUNA LANDINGS BY THE LONGLINE FISHERY OPERATING OUT ON BENOA, BALI
}

\author{
T.L.O. Davis ${ }^{\star}$, Sofri Bahar ${ }^{\star *}$, Nurzali Naamin ${ }^{\star *}$, J.H. Farley ${ }^{*}$, \\ and D. Le $e^{*}$
}

\begin{abstract}
The number of longline vessels operating out of Port of Benoa, Bali has increased steadily since 1986. However, this increase has been more rapid since 1994, and in 1996 there were 528 vessels registered in the port. Tuna exports peaked at 16,700 tonnes in 1993 but have since declined, despite the larger number of vessels in the fishery in 1996. Of the total landings, there was an increase in the proportion of bigeye tuna (Thunnus obesus) during this period. from $25 \%$ in 1993 to $41 \%$ in 1996 . Southern bluefin tuna (Thunnus maccoyii) remained a small component of the fishery, ranging from 4.1 to $5 \%$ of the total landings of tuna and billfish. The catch rate of southern bluefin tuna (SBT) declined slightly, although the high seasonality of the catch (reflecting the spawning season of this species) may obscure small trend. The catch rate of bigeye tuna varied without trend, except for a possible small increase during the last six month of 1996. Yellowfin tuna (Thunnus albacares) catch rates declined steadily over the period of monitoring. This declining catch rate is due partly to an increase in the targeting of bigeye at. the expense of yellowfin.
\end{abstract}

KEYWORDS: southern bluefin tuna (Thunnus maccoyii), bigeyetuna (T. obesus), yellowfin tuna (T. albacares), longline fishery, Benoa, Bali/Indonesia.

\section{INTRODUCTION}

Collaborative research between Commonwealth Scientific and Industrial Research Organization (CSIRO) Marine Research, Hobart, and the Research Institute of Marine Fisheries, Jakarta, was initialed in September, 1992 to monitor southern bluefin tuna caught by the longline fishery, operating out of Benoa. Southern bluefin tuna is a by catch of this fishery, which represent a significant proportion of the global catch for the species. Southern bluefin tuna is considered to be over-exploited (Anonim, 1994; Caton et al., 1990).

This fishery operates on their spawning ground, and catches mature southern bluefin tuna that have migrated from southern waters to spawn (Farley \& Davis, 1997). The fishery landings consist mainly of yellowfin and bigeye tuna, which are intented for export to Japan as fresh sashimi quality tuna (Davis et al., 1995). Landings have been monitored continuously since 1992, providing a useful time series of catch and biological data for this fishery. In this paper, we report on changes in the spawning component of the southern bluefin tuna population as well as changes in the fishery from 1993 to 1996.

\section{MATERIALS AND METHODS}

\section{Catch Monitoring}

We have attempted to record $30 \%$ of longline landings at the Port of Benoa. This means that the amount of sampling increased as the fishery developed. Total landings processed at P'I Perikanan Samodra Besar (PSB) have been monitored since 1992, while the landings of three companies processing at PT Sari Segara Utama (SSU), have been monitored since December 19913. In 1996, landings at four companies processing at PT Bandar Nelayan were also monitored. At each processing facility, the number and weight by species of all tuna processed for both export and domestic use was recorded. Individual dressed weights (gilled, gutted and definned) of southern bluefin tuna (SBT) were recorded at PSB, and individual dressed weights and most lengths of SBT were recorded at SSU and Bandar Nelayan. On average, 145 landings representing $30 \%$ of the longline fishery were monitored each month.

*) Researchers of CSIRO Division of Marine Research, Hobart, Tasmania, Australia

**) Researchers of the Research Institute for Marine Fisheries, Jakarta 


\section{Methods of Estimated Landing}

To provide monthly estimates of total landings in Bali, the monitored landings were multiplied by the reciprocal value of their export market share, except for landings by the PSB fishing company. This was because the company targeted bigeye tuna, and the species composition of their landings was not representative of the whole Benoa-based longline fishery (Davis et al., 1996). The PSB data were later included after the other landings were extrapolated to the whole Bali catch. The market share was estimated from the proportion of export monitored, to the total export permits issued for tuna and billfish by the Laboratory Quality Control and Fish Inspection Section of the Provincial Fisheries Service of Bali.

\section{RESULTS AND DISCUSSION}

\section{Trend in Longline Vessels Using the Port of Benoa}

Longline vessel registrations obtained from the Benoa Port Authority for the years 1986 to the resent indicate a steady increase in vessel using the port (Figure 1). In 1994 a number of Taiwanese vessel left Benoa and operated out of Bitung, North Sulawesi. This was in response to new regulations restricting the use of Benoa to vessel owned by Indonesian companies, resulting in a temporary reduction in the number of vessels using the port.
However, in 1995, many of these boats returned to Benoa as joint venture boats, renamed and flying the Indonesian flag. This has resulted in a marked increase in the number of boats from 242 in 1994 to 472 in 1995 , and 528 in 1996.

\section{Tuna Export}

The increase in longliners using the Port of Benoa was due to the development of fresh tuna export to Japan in 1998, which was made possible by the proximity of an international airport. Tuna and billfish export rose rapidly between 1988 and 1993 due to the increase in number of longliners using the port (Figure 1). Export peaked in 1993 at 16,700 tonnes, and but decreased in 1994 when many boats left the port. Export remained below 12,000 tonnes in 1994 and did not increase in 1995 despite the influx of boats back to the port late in that year. Export in 1996 increased to 14,555 tonnes when 528 vessels used the port, but this was well short of the 16,700 tonnes exported in 1993 when there were only 291 vessels.

\section{Species Composition of Landings}

Yellowfin tuna has been the dominant component of the fishery throughout four years (Figure 2). The two largest monthly landings of yellowfin were 1,934 tonnes in February 1993 and 1,956 tonnes in April 1995. The lowest monthly

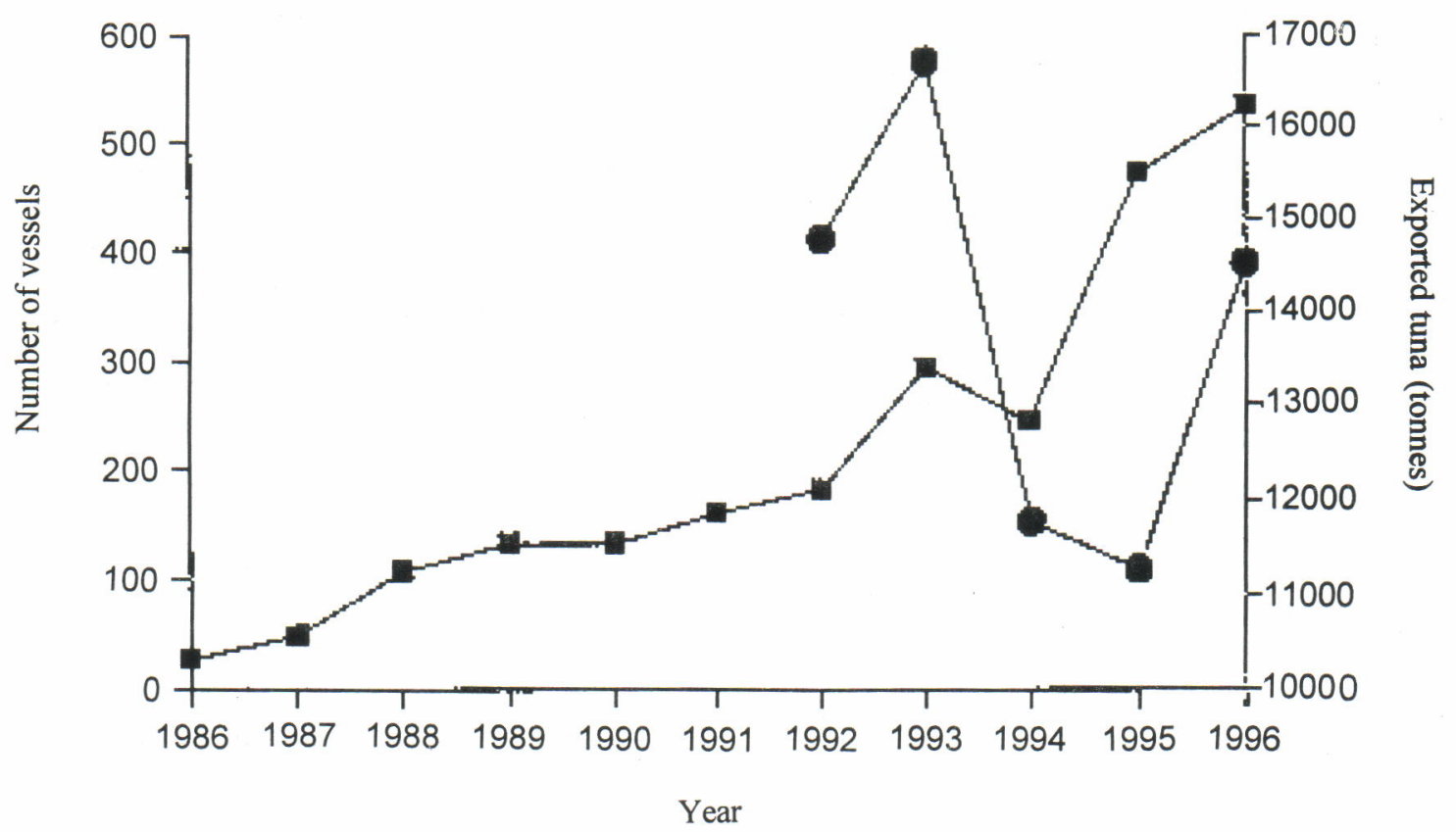

Figure 1. Number of longline vessels (squares) registered at the Port of Benoa, and export of tuna and billfish (circles) from Bali. Data supplied by Benoa Port Authority and DGF Provincial Fisheries Service of Bali, respectively. 
T.L.O. Davis, S. Bahar, N. Naamin, J.H. Farley, and D. Le

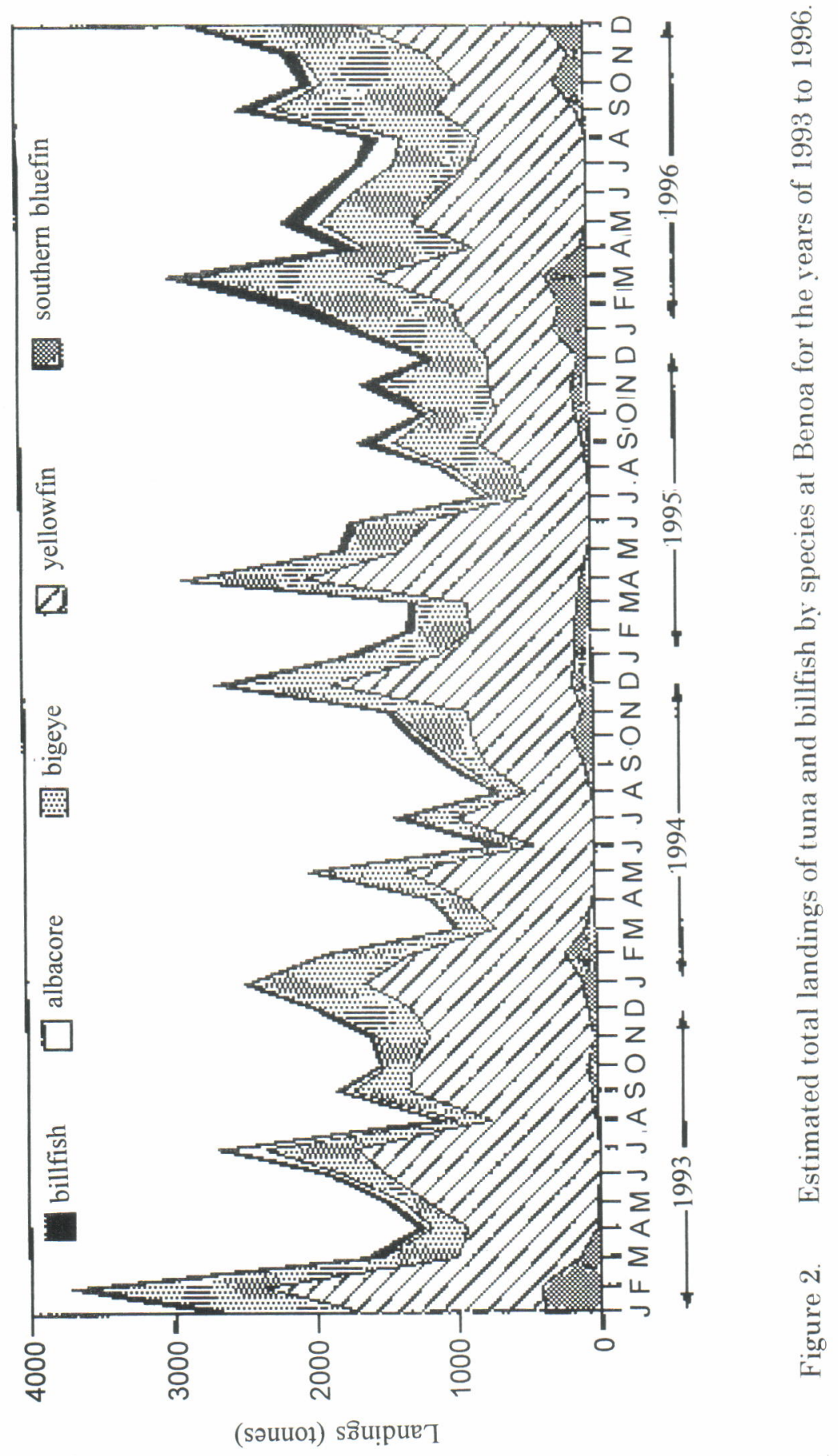


landing was 412 tonnes in June 1994. The yellowfin tuna catch appears highly variable. It does not follow any seasonal pattern, and generally is declining with time. This decline has been partly compensated for by an increase in landings of bigeye tuna over the same period.

Bigeye tuna comprised the second largest component of the longline catch. The largest landing of 1,220 tonnes of big eye occured in February, 1993. This level was not exceeded until 1,230 tonnes was caught in March 1996. Landing, again, did not appear to follow a seasonal pattern. Generally, the peaks and troughs in landing match those of yellofin tuna. There has been an increase in landing over time. This was seen more clearly in catches by year in 1993, bigeye accounted for $24.7 \%$ of landings and this figure increased to $41.4 \%$ in 1996, almost as large as the yellowfin component (Tabel 1).

In contrast, southern bluefin tuna landings fluctuate predictably around the spawning season which peaks from January to March (Farley \& Davis, 1997). The largest monthly catch of southern bluefin (428 tonnes) was caught in February, 1993. Since 1993, when the annual catch was 1,205 tonnes (Table 1), landings remained below 1,000 tonnes until 1996, when it peaked at 1,373 tonnes. The increase in southern bluefin landings in 1996 was expected because of anticipated increase in effort due to the influx of vessel into the Port of Benoa towards the end of 1995 (Davis et al., 1996). However, southern bluefin still remains a small component of the fishery, ranging from 4.1 to $5.5 \%$ of the total landings of tuna and billfish.

The total landing of tuna in 1996 was 25,083 tonnes caught by 528 longline vessels operating out of the Port of Benoa. This was only a little higher than the 23,557 tonnes landed in 1993 when there were only 291 vessels using the port. The port has grown considerably in terms of wharf area, processing plants and infrastructure. However, congestion in the port, and slow turn-around of vessels, has probably reduced the effective fishing time of each vessel. Only moderate increase in effort will occur in the future.

\section{Trend in Catch Rates}

Catch per unit of effort (CPUE) is expressed as the number of tuna landed per vessel fishing day. Some landing were excluded because the number of fishing days was not known, and there were insufficient data to calculate CPUE before December 1993. As well, the landings by PSB fishing company that targeted bigeye were not included. Fishing days appeared to be a fairly stable indicator of effort over this period, altough there had been a gradual increase in the average number of hooks per set each year (Table 2), resulting in a $10 \%$ increase over the three years.

CPUE for southern bluefin, bigeye and yellowfin tuna were plotted by month from December 1993 to July 1996 (Figure 3). Southern bluefin showed high seasonality in CPUE, reflecting the protracted spawning season each year. The seasonal nature of the fishery made it difficult to detect small changes in abundance. The average monthly (CPUE for the spawning period (September to April) was 0.23 southern bluefin/day in $1994 / 95$ compared to 0.21 in $1995 / 96$. These were the only two complete spawning seasons for which data were available.

Bigeye CPUE for the corresponding period showed considerable variability but no obvious seasonally. CPUE did not appear to decline over

Table 1. Estimate total and proportion (\%) of tuna and billfish in longline landings at Benoa from 1993 to 1996.

\begin{tabular}{crrrrrrrr}
\hline \multirow{2}{*}{ Species } & \multicolumn{2}{c}{1993} & \multicolumn{2}{c}{1994} & \multicolumn{2}{c}{1995} & \multicolumn{2}{c}{1996} \\
\cline { 2 - 9 } & Tonnes & $\%$ & Tonnes & $\%$ & Tonnes & $\%$ & Tonnes & $\%$ \\
\hline YFT & 15,023 & 63.8 & 11,188 & 62.9 & 10,566 & 57.7 & 10,868 & 43.3 \\
BET & 5,819 & 24.7 & 4,992 & 28.1 & 5,922 & 32.3 & 10,382 & 41.4 \\
SBT & 1,205 & 5.1 & 805 & 4.5 & 747 & 4.1 & 1,373 & 5.5 \\
ALB & 677 & 2.9 & 291 & 1.6 & 377 & 2.1 & 1,025 & 4.1 \\
BIL & 833 & 3.5 & 509 & 2.9 & 704 & 3.8 & 1,435 & 5.7 \\
\hline Total & 23,557 & 100.0 & \multicolumn{1}{c}{17,785} & 100.0 & 18,315 & 100.0 & 25,083 & 100.0 \\
\hline Remarks: & YFT = yellowfin tuna, BET = bigeye tuna, SBT = southern bluefin tuna, & &
\end{tabular}


T.L.O. Davis, S. Bahar, N. Naamin, J.H. Farley, and D. Le.

Tabel 2. Average number of hooks per longline set and the number of observations on which it was based.

\begin{tabular}{ccc}
\hline Year & Number of hooks & Number of landing \\
\hline 1993 & 1162 & 957 \\
1994 & 1154 & 558 \\
1995 & 1191 & 529 \\
1996 & 1294 & 1146 \\
\hline
\end{tabular}
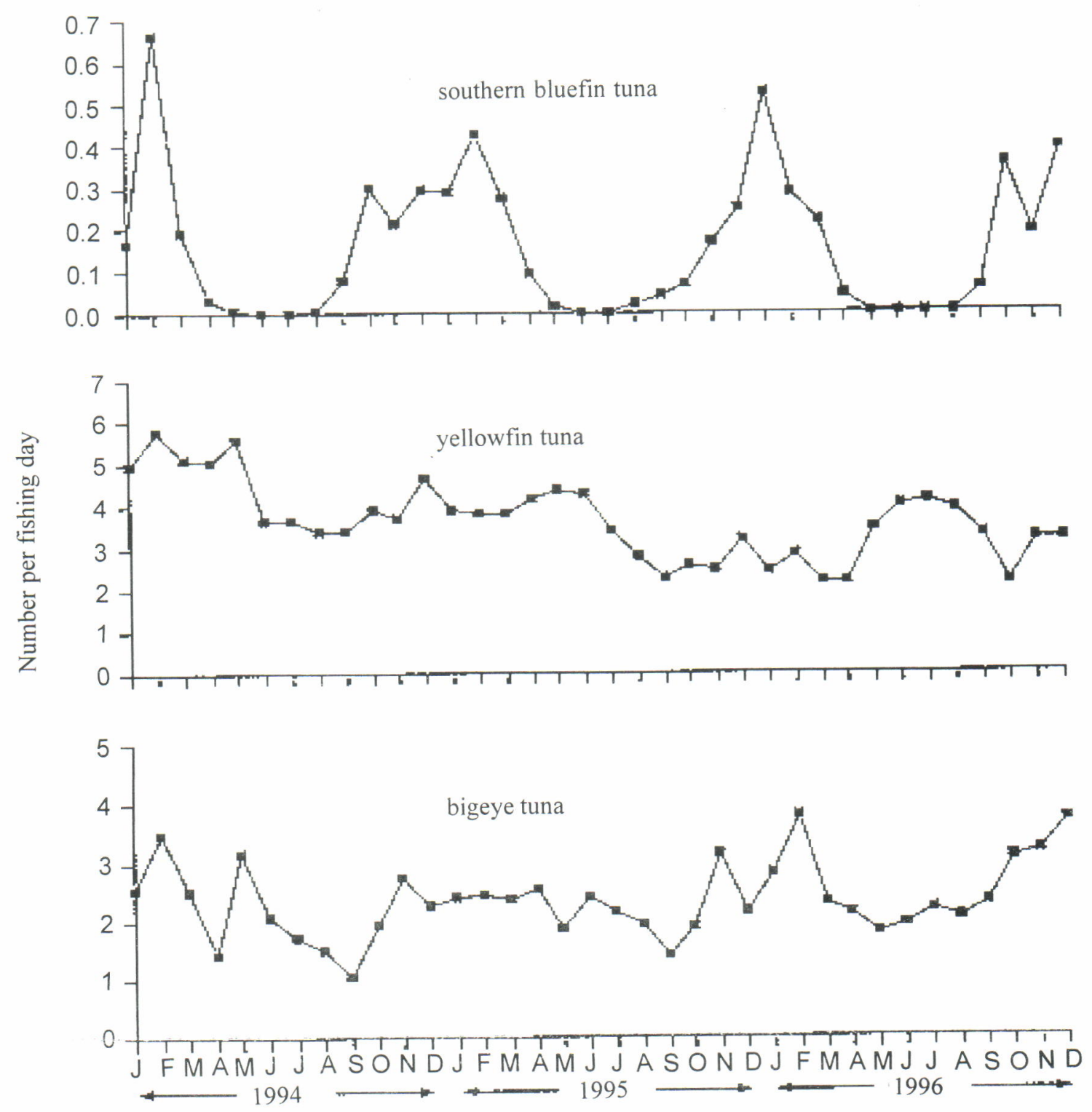

Figure 3. (YPUE, as measured by the number of fish caught per fishing day, by month for the years of 1994 to 1996. 
the period, and there had been a small but consistent increase in CPUE during the last six month of 1996 .

Yellowfin CPUE did not show seasonal variability, but nevertheless declined over the sampling period. These trends could be caused by changes in abundance, either driven environment or through fishing, or perhaps by changes in fishing methods to target bigeye.

\section{Trend in Targeting}

The relative proportions of southern bluefin, bigeye, and yellowfin in landings suggested widely differing fishing practices by individual longliners. The bigeye targeting index (proportion of bigeye to bigeye and yellowfin) varied from near zero to almost one (Figure 4). PSB vessels targeted bigeye, and most of their landings have a bigeye targeting index greater than 0.9. This was achieved largely by deeper longline sets (Davis et al., 1995). In 1993, PSB was the only company targeting and catching mainly bigeye. However, since then a number of other companies have ben successful incatching bigeye, and there has been a trend away from catches dominated by yellowfin towards mixed catches or catches dominated by bigeye.

This appears to influence the catch of southern bluefin (Figure 4). Where the targeting was achieved by deeper sets (such as those by the PSB fishing company), southern bluefin comprise less than $2 \%$ of the catch. However, at intermediate indices of bigeye targeting, some vessels were catching particularly high proportion of southern bluefin (up to $30 \%$ ). This trend is more marked in 1996 than in previous years. It is not known what fishing/targeting practices are involved in attaining these high catch rates for southern bluefin but, unlike the PSB fishing company, they probably do not rely on deeper long line sets. Such fishing practices may be of concern if measures need to be taken to conserve the spawning stock of southern bluefin tuna.

\section{Trend in Export}

Tuna is graded into export and non-export quality at the processing factories. The proportion of southern bluefin graded as export quality has declined over the years of 1993 to 1996 (Figure 5). The proportion of yellowfin and bigeye graded as export quality has also decreased slightly. These changes may be due to more critical grading for export. It may also be because fish are of poorer quality. The rapid increase in vessels in the Port of Benoa may have streched the capacity of the port infrastructure to support frequent landings and rapid processing of fish of resulting in poorer fish quality. Consistent with increased congestion in the port, there is a trend for fishing boats to trans-ship catches and be re-supplied with fuel, bait and ice by carrier boats, thus reducing the number of port visits.

Some albacore were exported when monitoring started in 1992 (Figure 5), but none has been exported from company monitored since September 1993. A very small proportion of billfish is exported.

\section{Size Composition of SBT in Monitored Landings}

Weight-frequency histograms for southern bluefin had been plotted by year for the years of 1993 to 1996 (Figure 6), and length-frequency histograms for the years of 1994 to 1996 (Figure 7). Lengths measured in 1993 were not included because of problems detected in the length measurement (Davis et al., 1996).

There have been no major changes in weight distribution over the four years. However, variation in condition might have confounded detection of trends between years. The 100-110 kg classes had beeen well represented in all years and were the major classes in 1996.

The length frequency distributions of southern bluefin differed between years. In 1995, there was a greater proportion of southern bluefin larger than $180 \mathrm{~cm}$ than in the previous year. The 1996 length distributions were more similar to those of 1994 than 1995. There was a slight increase in the proportion of southern bluefin smaller than $165 \mathrm{~cm}$ in 1996 compared to previous year. It is not known whether this is due to an increase in recruitment of smaller fish. An increase in recruitment of smaller fish is expected if the reduction in catch quotas, introduced in $\mathbf{1 9 8 4}$. have had the desired effect and enabled more fish to survive to maturity. However, given our current understanding of mean age at first maturity, and the presence of strong cohorts from the 1985-89 year classes (Gunn et al., 1996), an increase in recruitment to the spawning grounds is expected in four years. Further monitoring of the spawning population is needed to determine whether this is the case.

\section{CONCLUSIONS}

The number of longline vessels operating out of the Port of Benoa reached a historical high of 

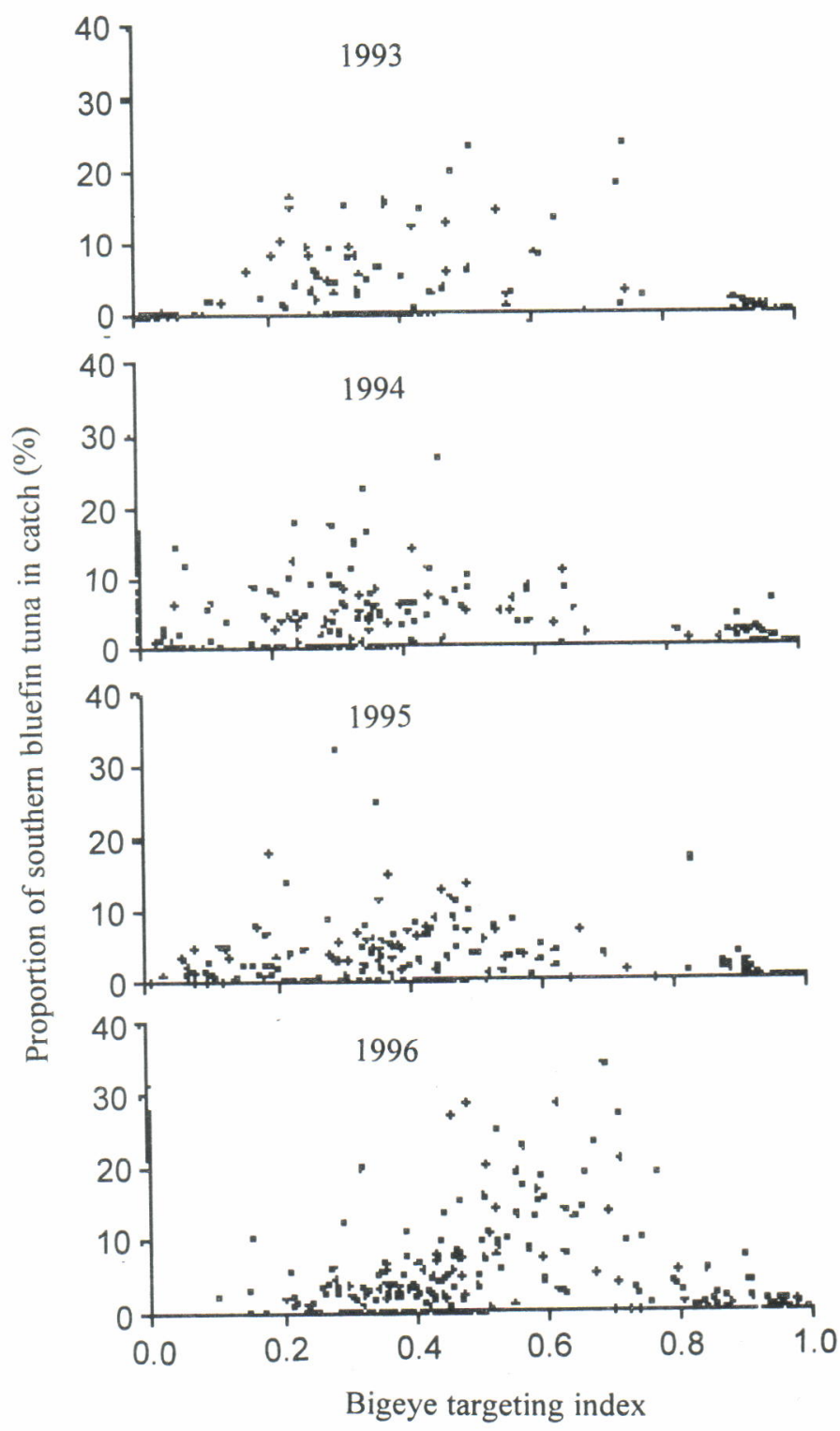

Figure 4. Percentage of bluefin in yearly tuna landings of individual longliners plotted againts the bigeye targeting index (bigeye/bigeye + yellowfin). Only those vessels landing more than 10 tonnes of tuna in each year are included.

528 in 1996. The amount of tuna exported from Bali in 1996 was 14,500 tonnes, which is less than the 16,700 tonnes exported in 1993 when there were only 291 vessels using the port. The poor export performance in relation to the large number of vessels operating in 1996 can be attributed to limitations of the port to service so many vessels and to process the catches. Further expansion of the fleet will depend on the development of new port facilities

There has been a shift in the species caught in fishery, from mainly yellowfin tuna in 1993 and 1994 to equal amounts of yellowfin and bigeye tuna in 1996. It is not known to what extend the changes in species caught is due to shifting targeting practices, or changes in abundance of yellowfin and bigeye tuna. Southern bluefin tuna remained a small component of the fishery in 1996 , but was a significant part (13\%) of the global catch for this species.

\section{ACKNOWLEDGMENTS}

We wish to thank the managers at P'I' Perikanan Samodra Besar (PSB), PT Sari Segara Utama (SSU) and P'T Bandar Nelayan for facilitating catch sampling at their processing plants. We are grateful to Kiroan Siregar, Labuhan Siregar, Mashar Machmud and Waluyo for 

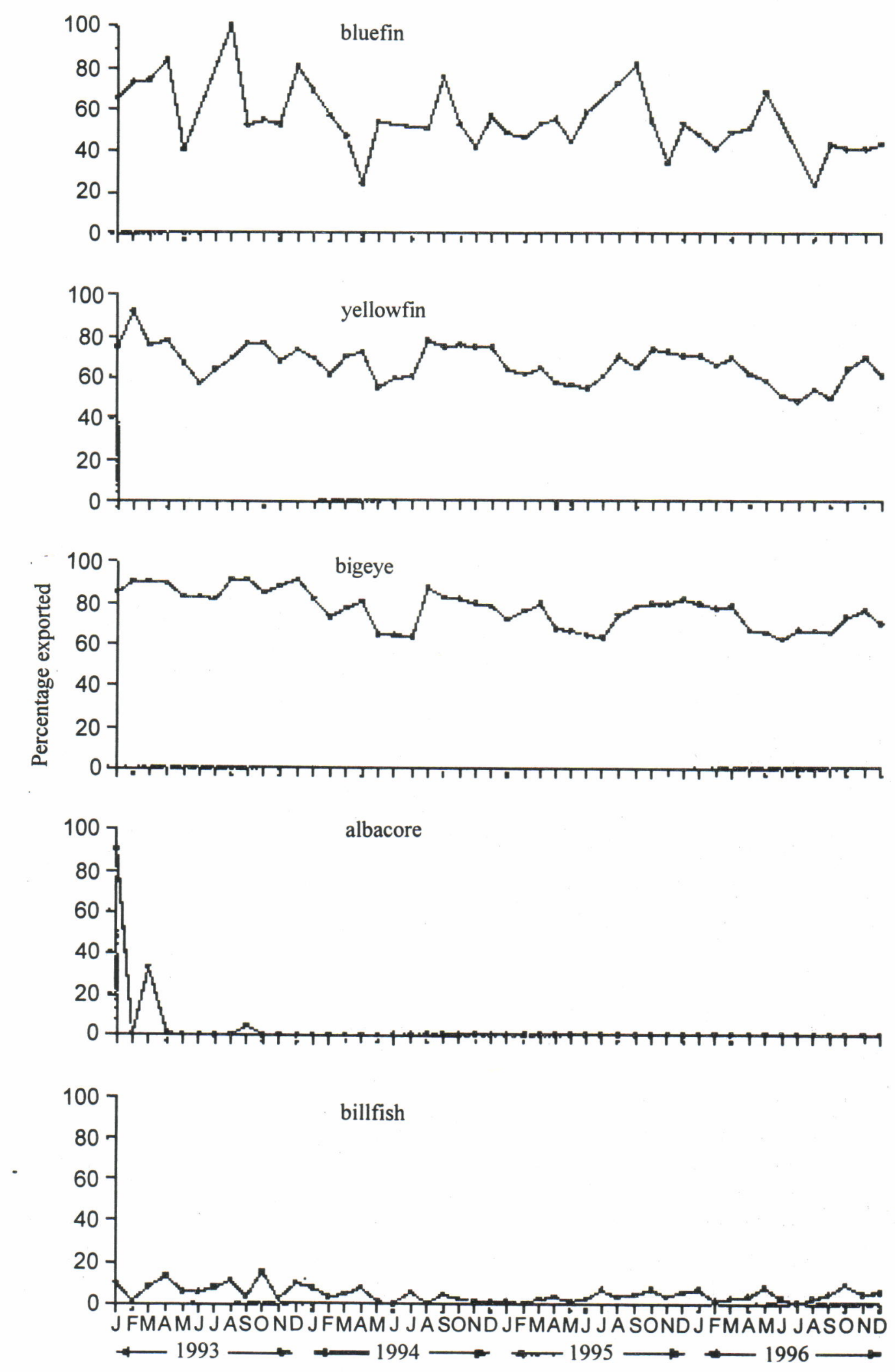

Figure 5. Percentage of each species selected for export each month during the years of 1993 to 1996. 
T.L.O. Davis, S. Bahar, N. Naamin, J.H. Farley, and D. Le
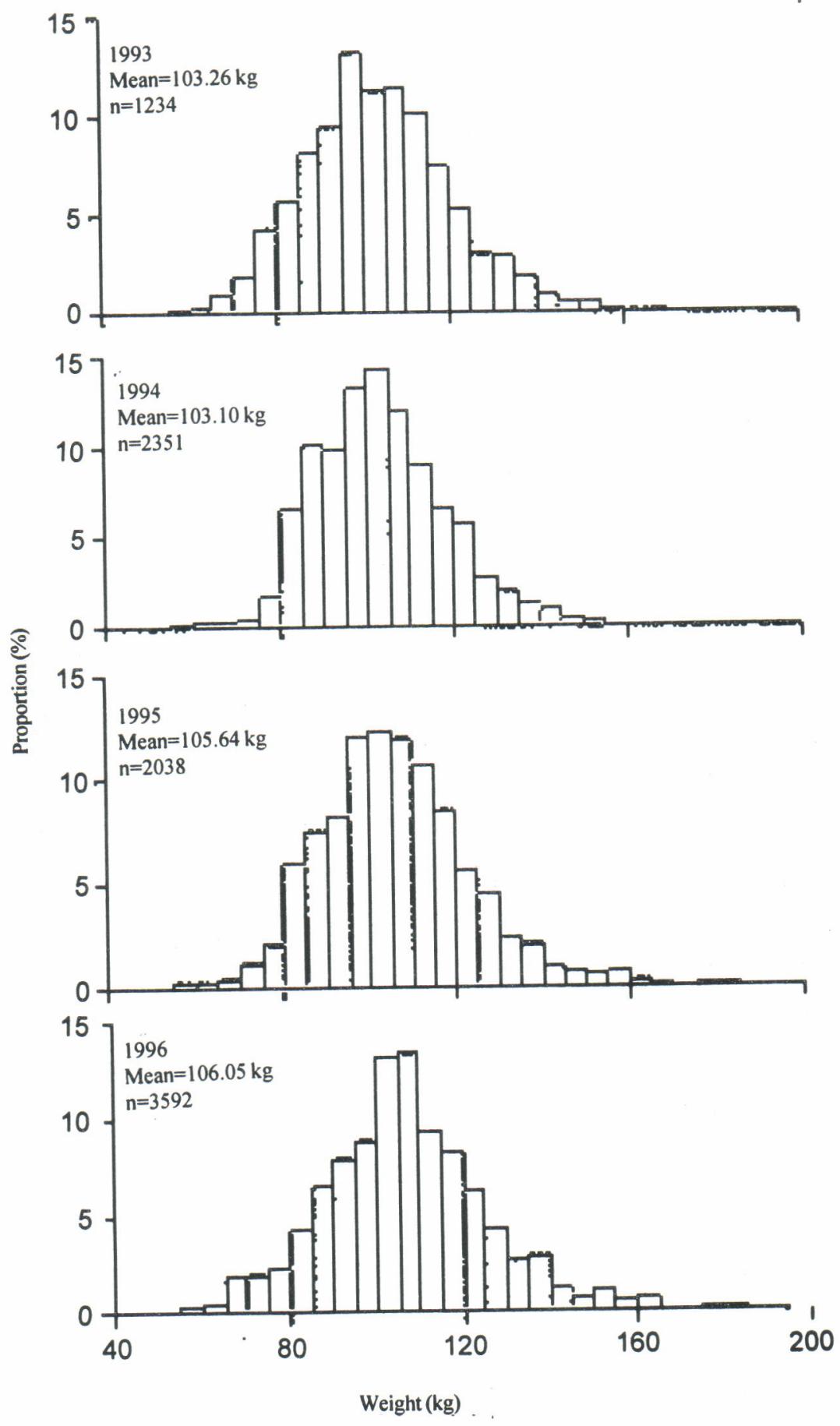

Figure 6. Weight frequency histogram (5 kg intervals) of southern bluefin tuna measured in 1993 to 1996. 

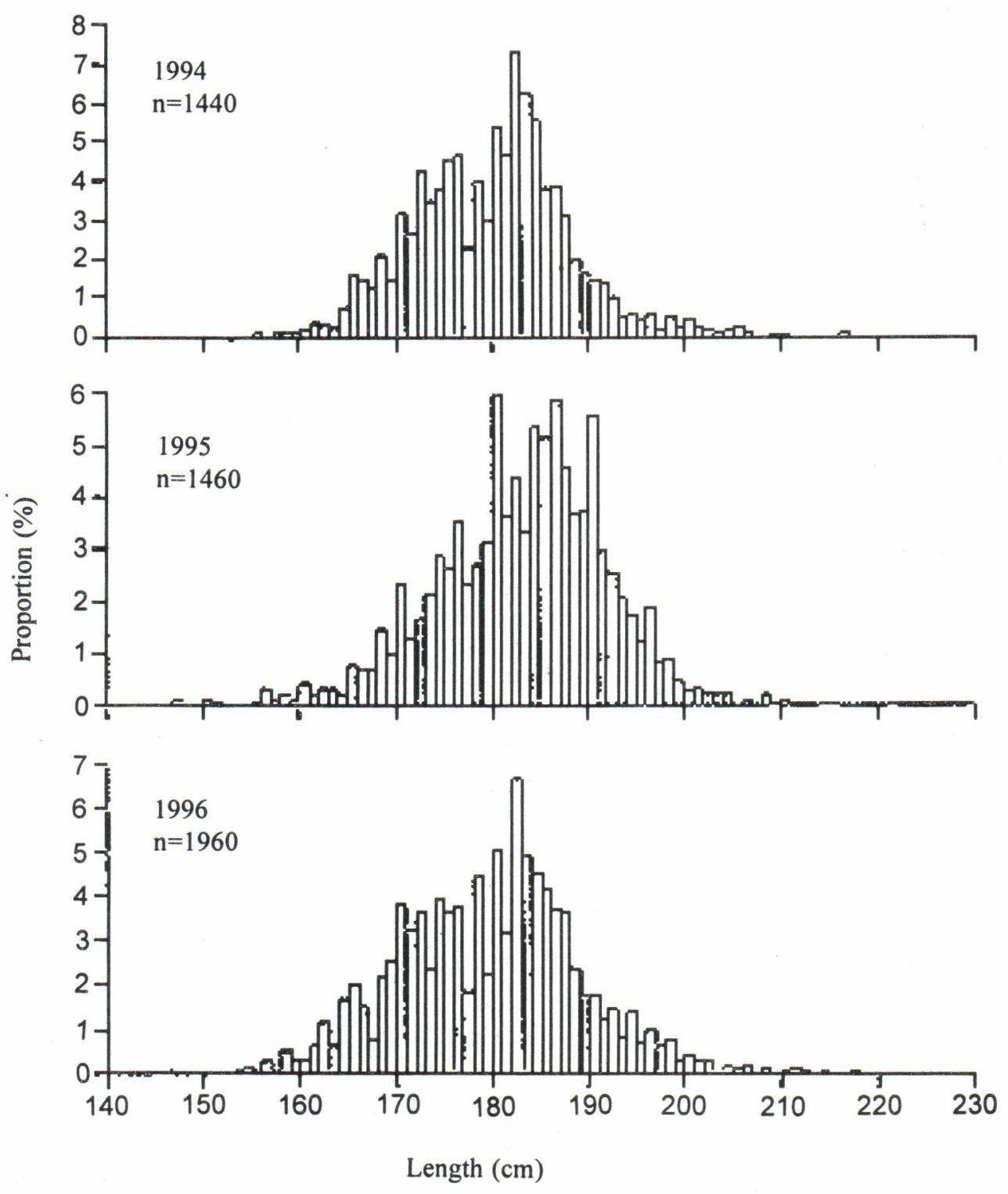

Figure 7. Length frequency histogram (1 cm intervals) of southern bluefin tuna measured in 1994 to 1996.

monitoring catches at the various plants. This research was supported by Fisheries Resources Research Fund Grants from the Australian Fisheries Management Authority.

\section{REFERENCES}

Anonim. 1994. Report of the thirteenth meeting of Australian, Japanese and New Zealand scientists on southern bluefin tuna. Report to Management. 20-29 April, 1994 Wellington, New Zealand. 13 pp.

Caton, A., Mcloughin, K. and Williams, M.J. 1990. Southern Bluefin Tuna; Scientific Background to the Debate. Australian Government Publishing Service, Canberra. 41 pp.
Davis, T., Bahar,S. and Farley, J. 1995. Southern bluefin tuna in Indonesian longline fishery: Historical development, composition, season. some biological parameters, landing estimation and catch statistics for 1993. Indonesian Fish. Res. J. 1: 68 . 86

Davis, T.L.()., Farley, J.H. and Bahar, S. 1996. (Catch monitoring of the fresh tuna caught by the Balibased longline fishery. Report for the CCSSBT Scientific Meeting, 26 August-5 September, 1996, Hobart, Australia. CCSBT/SC/96/6.

Farley, J.S and Davis, T.L.(). 1997. Reproductive dynamics of southern bluefin tuna, Thunnus maccoyii. U.S. Fish. Bull. 96: 223-236. 
T.L.O. Davis, S. Bahar, N. Naamin, J.H. Farley, and D. Le

Gunn, J.S., Davis, T.L.O., Farley, J.H., Clear, N.P. and Haskard, K.A. 1996. Preliminary estimates of the age structure of the SBT spawning stock. Report for the CCSBT Scientific Meeting, 26 August - 5 September, 1996, Hobart, Australia. CCSBT/SC/ 96/10. 